\title{
A perspective of citrus Huanglongbing in the context of the Mediterranean Basin
}

\author{
Nian Wang ${ }^{1}$ \\ Received: 30 October 2019 / Accepted: 2 April 2020 / Published online: 23 April 2020 \\ (C) The Author(s) 2020
}

\begin{abstract}
Huanglongbing (HLB) is one of the most catastrophic citrus diseases. HLB pathogens Candidatus Liberibacter asiaticus (Las), $C a$. L. africanus (Laf), and $\mathrm{Ca}$. L. americanus (Lam) and their insect vectors Asian citrus psyllids (ACP, Diaphorina citri) and African citrus psyllids (AfCP, Trioza erytreae) are invading citrus producing regions where HLB was absent previously, including the Mediterranean basin. Importantly, the Mediterranean region is one of the two major citrus producing areas without HLB. Here, I provide a short perspective regarding a) information related to the distribution of the HLB pathogens and psyllid vectors in this region and neighboring countries, b) predicted distribution of the HLB for this region, c) the possible evolution of Liberibacters and how they could have established their relationship with different hosts, and d) approaches to fend off HLB. Specifically, I emphasized the following measurements: quarantine measures against AfCP, ACP, Las, Laf, and Lam, early detection and diagnosis of HLB and removal of inoculum, surveillance of AfCP and ACP and eradication of citrus psyllids once identified.
\end{abstract}

Keywords Citrus $\cdot$ HLB $\cdot$ Huanglongbing $\cdot$ Liberibacter $\cdot$ Phloem $\cdot$ Psyllids

Citrus Huanglongbing (HLB), also known as citrus greening, is the most devastating disease in many citrus producing areas worldwide. HLB is caused by Candidatus Liberibacter asiaticus (Las), $C a$. L. africanus (Laf), and $C a$. L. americanus (Lam) that are yet to be cultured (Merfa et al. 2019). Among them, Las is the most widely distributed and has been reported in Asia, North America, South America, and Africa, Laf is only present in Africa, and Lam, originally identified in Brazil, is diminishing and being taken over by Las. Las and Lam are naturally transmitted by Asian citrus psyllids (ACP, Diaphorina citri) and Laf by African citrus psyllids (AfCP, Trioza erytreae). The HLB pathogens and insect vectors have been spreading to new territories including Brazil (ColettaFilho et al. 2004; Texeira et al. 2005), multiple states of the United States (Kumagai et al. 2013); Belize (Manjunath et al. 2010); countries in the Caribbean including Cuba (Martinez et al. 2009) and the Dominican Republic (Matos et al. 2009);

Nian Wang

nianwang@ufl.edu

1 Citrus Research and Education Center, Department of Microbiology and Cell Science, University of Florida/Institute of Food and Agricultural Sciences, Lake Alfred, FL, USA
Bhutan (Doe et al. 2003); and Ethiopia (Saponari et al. 2010). Currently, the Mediterranean Basin and Australia are the two major citrus producing regions that are free of HLB. Despite the challenges to study the Liberibacters, a lot of exciting progress has been made in understanding the citrus HLB pathosystem that have been reviewed extensively (Bové 2006; Gottwald 2010; Wang and Trivedi 2013; Wang et al. 2017; Bendix and Lewis 2018; Blaustein et al. 2018; Coyle et al. 2018; Munir et al. 2018; Zheng et al. 2018; Kruse et al. 2019). Here, I will therefore focus on some areas that have not been reviewed intensively in the past and tailor it to the Mediterranean citrus producing region for the readership of the journal, and summarize some perspectives regarding how this region can fend off the invasion by HLB.

\section{HLB at the doorstep of the Mediterranean Basin}

Las and ACP were reported in the neighboring countries of the Mediterranean Basin: Iran (Faghih et al. 2009) and Saudi Arabia (Bové 2006). Las and ACP were also reported in several African countries that are not adjacent to the Mediterranean Basin: Tanzania (Shimwela et al. 2016) and 
Uganda (Kalyebi et al. 2015). However, the identification of Las in those two countries have been challenged by Roberts and colleagues as probable misidentifications that were reclassified as $\mathrm{Ca}$. L. africanus subsp. clausenae (Roberts et al. 2017). Only Las but not ACP was reported in Ethiopia (Saponari et al. 2010). Only ACP but not Las is present in the United Arab Emirates and Oman. Both Laf and AfCP are present in Saudi Arabia, Yemen, Burundi, Cameroon, Central African Republic, Comoros, Ethiopia, Kenya, Madagascar, Malawi, Mauritius, Réunion, Rwanda, Saint Helena, Somalia, South Africa, Swaziland, Tanzania, Uganda, and Zimbabwe. In addition, AfCP has been reported in Spain and Portugal even though HLB pathogens have not been found in either place (Cocuzza et al. 2017). AfCP has been shown experimentally to transmit Las (Massonié et al. 1976) and carry Las in field populations of AfCP in Ethiopia (Ajene et al. 2019). On the other hand, ACP is also known to transmit either Las or Laf under experimental conditions (Lallemand et al. 1986). Thus, HLB and its vectors present an immediate threat to the citrus industry of the Mediterranean Basin, echoing the concerns by many esteemed European colleagues (Aubert 2011; Bové 2014; Duran-Vila et al. 2014; Janse 2012; Siverio et al. 2017).

\section{Perspective distribution of HLB in the Mediterranean Basin}

Las prefers temperatures $>30^{\circ} \mathrm{C}$ whereas Laf thrives at temperatures less than $30^{\circ} \mathrm{C}$ (Jagoueix et al. 1994). Las appears to have a wider tolerance to temperature $\left(10.1\right.$ to $\left.38^{\circ} \mathrm{C}\right)$ than its psyllid vector $\left(12.85\right.$ to $37^{\circ} \mathrm{C}$ ) (Gutierrez and Ponti 2013). AfCP is sensitive to hot and dry conditions and favors cool and moist areas. Gutierrez and Ponti (2013) predicated the prospective distribution of Las and ACP and suggested that North Africa, southern Spain and the Middle East are most suitable for Las, whereas the rest of southern Europe has intermediate favorability for Las. Furthermore, the authors suggested that ACP is more restricted in term of its prospective distribution. Overall, the authors suggested that both Las and ACP have the capacity to invade all of the citrus growing regions of the Mediterranean Basin. Another predication suggested large areas of Africa are suitable for ACP and Las, the Mediterranean area is moderately suitable for ACP but less suitable for Las, except for that in southern Portugal and Spain (Narouei-Khandan et al. 2016). However, one of the models predicated that Mediterranean countries in North Africa and southern Europe are highly suitable for Las (NaroueiKhandan et al. 2016). Risk analysis for Laf and AfCP has not been reported previously. However, AfCP has already been reported in northwestern Iberian Peninsula of Spain and Portugal (Cocuzza et al. 2017) even though neither Laf nor Las is currently present in the Mediterranean region. AfCP has also shown capacity to adapt and establish in new citrusproducing regions of the world with different environmental conditions by spreading and invading over 30 countries in Africa, Europe and Asia (https://www.cabi.org/isc /datasheet/54914, accessed on March 5, 2020).

\section{Potential evolutionary pathways of Liberibacters}

Understanding the evolution of Liberibacters might help prevent or prepare for the emergence of new diseases resulting from Liberibacters infecting new hosts. So far, seven $\mathrm{Ca}$. Liberibacter species have been reported including HLB causal agents Las, Laf, and Lam, $\mathrm{Ca}$. L. solanacearum (Lso, syn. $\mathrm{Ca}$. L. psyllaurous) causing diseases on many solanaceous plants and on carrot, celery, parsley, and parsnip, $\mathrm{Ca}$. L. europaeus (Leu) infecting scotch broom (Thompson et al. 2013), L. crescens (Lcr), and Ca. L. brunswickensis (Lbr) (Hansen et al. 2008; Jagoueix et al. 1994, 1997; Leonard et al. 2012; Liefting et al. 2008; Morris et al. 2017; Raddadi et al. 2011; Texeira et al. 2005; Thompson et al. 2013). One potential explanation of the evolutionary pathway of Liberibacters is "plant-first model". Ca. Liberibacter spp. belong to alphaproteobacteria and are phylogenetically related to Rhizobium and Sinorhizobium that are capable of endocytosis, a phenomenon through which bacteria can get inside the cytoplasm (Verma 1992). Even though endocytosis is very common for bacteria infecting mammals, only few plant associated bacteria are capable of entering the cytoplasm of plant cells. It was suggested that ancestors of Liberibacters first established their presence inside the phloem of legume ancestors via endocytosis (Wang 2019) (Fig. 1). Liberibacters inside the phloem further established their association with phloem-sucking psyllid ancestors. Subsequent host jumps of psyllids led to divergence of different $\mathrm{Ca}$. Liberibacter species. Interestingly, both Laf and Lam might have gone through a host jump to cause HLB on citrus (Wang et al. 2017). It was suggested that multiple Laf subspecies $C a$. L. africanus subsp. capensis, $C a$. L. africanus subsp. clausenae, $C a$. L. africanus subsp. vepridis, $C a$. L. africanus subsp. zanthoxyli, and $C a$. L. africanus subsp. tecleae were present in indigenous rutaceous species in Africa such as Calodendrum capense, Clausena anisate, Vepris lanceolate, or Zanthoxylum capense (Garnier et al. 2000; Roberts et al. 2015; Roberts and Pietersen 2017) before the introduction of citrus, suggesting HLB-causing Laf has evolved from the ancestor of Laf subspecies via host jump (Phahladira et al. 2012; Roberts et al. 2015). Another possibility for Liberibacter origin is described in the "insect-first model" that suggests Liberibacters have been initially insect commensals that have evolved to be associated with the phloem tissues following repeated inoculations by insects (Bové and Garnier2002; Nadarasah and Stavrinides 2011). 


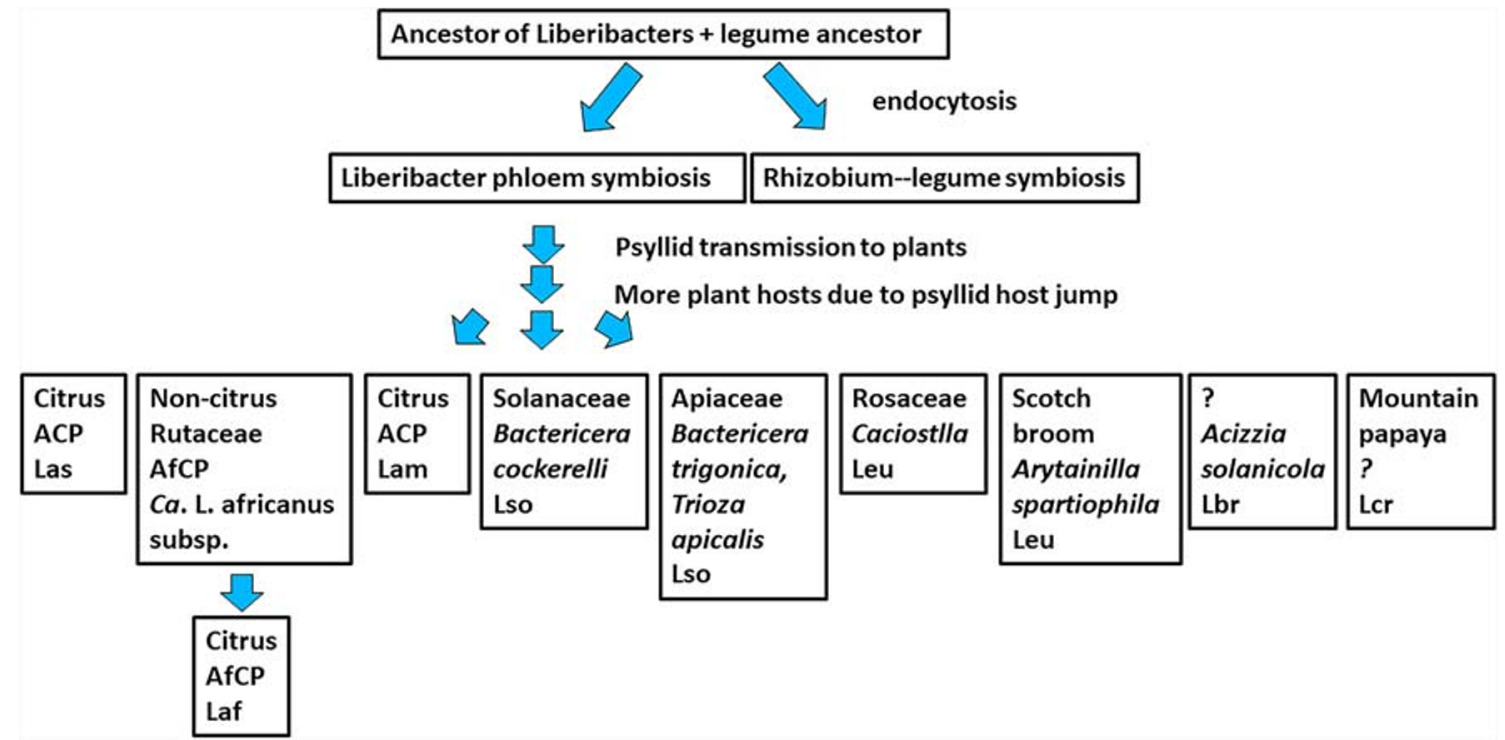

Fig. 1 Evolution of Candidatus Liberibacter. The ancestor of Liberibacters is capable of endocytosis. The ancestor of Liberibacters and the ancestor of legume have evolved two different symbiosis relationships, with one represented by the Rhizobium-legume symbiosis, and the phloem symbiosis represented by Candidatus Liberibacter. The relationship between psyllid ancestor and legume ancestor allows the transmission of Liberibacter. Psyllid host jump further expands host range

\section{Fending-off HLB}

As clearly pointed out by Bové (2006), the best strategy against HLB is to prevent the introduction, and establishment rather than to cure the HLB disease. To fend off HLB in the Mediterranean region and other HLB-free citrus production regions, the following measures are emphasized: a) quarantine measures against AfCP, ACP, Las, Laf, and Lam, b) early detection and diagnosis of HLB and its vectors, c) removal of inoculum, surveillance of AfCP and ACP and eradication of citrus psyllids once identified. The recommendations mentioned here are by no means comprehensive. The readers are referred to many excellent recommendations that have been reviewed before (Bové 2006; Cocuzza et al. 2017; Duran-Vila et al. 2014).

\section{Quarantine}

Human-mediated spread is an important trajectory for many agricultural pests (Shigesada and Kawasaki 1997). Introduction of HLB to new territories mediated by human activities has been reported in many cases. For example, all the HLB-positive trees in California identified in the early stage of introduction are in the residential locations, suggesting human-mediated introduction. In addition, human activities such as movement of fruit and/or plant material are suggested to be necessary for long distance dispersion of $D$. citri (Halbert et al. 2010). Due to the relative isolation of the citrus production areas in the Mediterranean Basin from other citrus of Liberibacters. Las: Candidatus Liberibacter asiaticus; $C a$. L. africanus includes: $C a$. L. africanus, $C a$. L. africanus subsp. capensis, $C a$. L. africanus subsp. clausenae, $C a$. L. africanus subsp. vepridis, $C a$. L. africanus subsp. zanthoxyli, $\mathrm{Ca}$. L. africanus subsp. tecleae; Lam: $\mathrm{Ca}$. L. americanus; Leu: $C a$. L. europaeus; Lso: $C a$. L. solanacearum; Lbr: Ca. L. brunswickensis; Lcr: L. crescens; ACP: Asian citrus psyllid; AfCP: African citrus psyllid

production areas in the world, quarantine measures for citrus materials (e.g., budwood, grafted trees, seedlings) as well as ornamental rutaceous species (e.g., Murraya) have been suggested and implemented to prevent the introduction of HLB pathogens and psyllid vectors (Duran-Vila et al. 2014). However, hurricanes or storms have been suggested to play important roles in long distance dispersal of Asian citrus psyllids (Gottwald 2010; Wang et al. 2017), suggesting other approaches beyond quarantine are required to prevent HLB/ psyllid from infecting and/or spreading in the Mediterranean Basin.

\section{Surveillance of psyllids}

Monitoring and surveillance of ACP and AfCP in citrus groves, on citrus and ornamental rutaceous trees elsewhere is one of the approaches that contribute to psyllid prevention. Monitoring ACP or AfCP can be conducted by visual inspection of eggs and nymphs on flush shoots (Sétamou et al. 2008), and monitoring of adult populations using sticky traps (Hall et al. 2010; Sétamou et al. 2014), stem tap sampling (Stansly et al. 2009), vacuum sampling (Thomas 2012), and/ or sweep nets (Stansly et al. 2009). Among them, yellow or lime-green sticky cards are currently the most sensitive and effective method for detecting adult citrus psyllids and monitoring their populations (Hall and Hentz 2010; Monzo et al. 2015). To improve trapping efficiency, scientists have tested vibrational duetting mimics (Mankin et al. 2016), odorants released by citrus plants that attract ACP (Coutinho-Abreu 
et al. 2014), and sex pheromone (Zanardi et al. 2018). In addition, a strong edge effect in $D$. citri distribution in the groves has been reported by multiple groups, which will guide the efficient setup of traps to monitor ACP and AfCP (Gottwald 2010).

\section{Eradication of ACP or AfCP}

Eradication of invasive pests may provide a sensible outcome. Hundreds of successful insect eradication projects have been reported (Tobin et al. 2014; Kean et al. 2015). For example, Tobin et al. (2014) analyzed 672 arthropod eradication programs and found 395 of them were considered successful, and Kean et al. (2015) reported 508 successful eradication programs. The successful eradication operations include elimination of Orgyia thyellina (Lepidoptera: Lymantriidae) in New Zealand (Myers and Hosking 2002; Suckling et al. 2007); the screwworm fly [Cochliomyia hominivorax (Coquerel)] in the United States (Myers et al. 1998), and the Mediterranean fruit fly [Ceratitis capitata (Wiedemann)] in New Zealand (Holder et al. 1997). Eradication of ACP and AfCP was conducted in Australia and in the Madeira and the Canary Islands, respectively, unfortunately with opposite outcomes. ACP was reported from Australia in 1922, but it was eradicated successfully (Bellis et al. 2005). On the other hand, the eradication programs of AfCP in the Madeira and the Canary Islands, where AfCP was reported in Madeira in 1994 (Carvalho and Aguiar 1997) and the Canary Islands in 2002 (González-Hernández 2003), failed (Cocuzza et al. 2017). ACP was identified in Florida in 1998, but eradication of ACP was never conducted, leading to its establishment in Florida, and subsequent devastating effect on the citrus industry by spreading the HLB pathogen. ACP is currently under eradication in Southern California. However, it remains to be seen whether such an eradication program will be fruitful. Despite the many concerns regarding AfCP eradication, it might be the best solution to prevent more costly, and devastating challenges of the HLB introductions. Historically, HLB breakouts usually follow the introduction and establishment of citrus psyllids especially ACP although sometimes only many years later, such as in Brazil. New flush shoots are the primary resources for psyllid oviposition and immature development (Catling 1970; Hall et al. 2013), which represent an Achilles' heel of psyllids when trying to eliminate them.

\section{Early detection and diagnosis of HLB}

Immediate detection and correct diagnosis of HLB after introduction, followed by eradication measures, are critical to prevent its further spreading. Education of the stakeholders, including growers, regulatory agents, and the public, is critical for symptoms based identification. Monitoring Las and Laf in psyllids is also required. There should also be monitoring of eventual wild hosts, especially Murraya paniculate and related and hosts in domestic areas. A simple method has been developed to detect Las right after psyllid feeding, which allows early detection of Las before HLB symptom appearance (Pandey and Wang 2019). Importantly, canines have shown excellent sensitivity and accuracy in detecting Las directly rather than only host volatiles produced by the infection (Gottwald et al. 2020), which might help both in early detection of Las in the citrus groves and backyards as well as in quarantine measures.

\section{Concluding remark}

HLB represents a real and unprecedented threat to the Mediterranean region. To fend off HLB, it needs a coordinated effort by regulatory agencies, plant protection agencies, growers, scientists and the public in different countries of the Mediterranean region to prevent the introduction of HLB, eradicate AfCP and/or prevent its further introduction and spreading, and prevent the ACP introduction. Efforts are also needed to find long-term solution such as developing resistant citrus varieties against HLB or ACP and AfCP as rightly pointed out by Duran-Vila et al. (2014).

Acknowledgments This work has been supported by Florida Citrus Initiative Program, Citrus Research and Development Foundation, USDA MAC program, USDA National Institute of Food and Agriculture grant \# 2018-70016-27412.

Open Access This article is licensed under a Creative Commons Attribution 4.0 International License, which permits use, sharing, adaptation, distribution and reproduction in any medium or format, as long as you give appropriate credit to the original author(s) and the source, provide a link to the Creative Commons licence, and indicate if changes were made. The images or other third party material in this article are included in the article's Creative Commons licence, unless indicated otherwise in a credit line to the material. If material is not included in the article's Creative Commons licence and your intended use is not permitted by statutory regulation or exceeds the permitted use, you will need to obtain permission directly from the copyright holder. To view a copy of this licence, visit http://creativecommons.org/licenses/by/4.0/.

\section{References}

Ajene IJ, Khamis F, Mohammed S, Ombura FL, Rasowo B, Pietersen G, van Asch B, Ekesi S (2019) First report of field population of Trioza erytreae carrying the Huanglongbing associated pathogen, Candidatus Liberibacter asiaticus, in Ethiopia. Plant Dis. https:// doi.org/10.1094/PDIS-01-19-0238-PDN

Aubert B. 2011 A new threat to Mediterranean citrus. Published on 29/06/ 2011 - published by FruiTrop 168, 4-9

Bellis G, Hollis D, Jacobson S (2005) Asian citrus psyllid, Diaphorina citri Kuwayama (Hemiptera: Psyllidae), and huanglongbing disease 
do not exist in the Stapleton Station area of the Northern Territory of Australia. Aust J Entomol 44:68-70

Bendix C, Lewis JD (2018) The enemy within: phloem-limited pathogens. Mol Plant Pathol 19:238-254

Blaustein RA, Lorca GL, Teplitski M (2018) Challenges for managing Candidatus Liberibacter spp. (Huanglongbing disease pathogen): current control measures and future directions. Phytopathology 108:424-435

Bové JM (2006) Huanglongbing: a destructive, newly-emerging, century-old disease of citrus. J Plant Path 88:7-37

Bové JM (2014) Huanglongbing or yellow shoot, a disease of Gondwanan origin: will it destroy citrus worldwide? Phytoparasitica 42:579-583

Bové JM, Garnier M (2002) Phloem-and xylem-restricted plant pathogenic bacteria. Plant Sci 163:1083-1098

Carvalho JP, Aguiar AMF (1997) Pragas doss citrinos na Ilha da Madeira. Funchal. Regiao Auto'noma da Madeira. Secreteria Regional de Agricultura Florestas e Pescas. Direccao Regional ricultura, p 410

Catling HD (1970) Distribution of psyllid vectors of citrus greening disease with notes on the biology and bionomics of Diaphorina citri. Food Agric. Org., Plant Protection Bull 18:8-15

Cocuzza GEM, Alberto U, Hernández-Suárez E, Siverio F, Di Silvestro S, Tena A, Carmelo R (2017) A review on Trioza erytreae (African citrus psyllid), now in mainland Europe, and its potential risk as vector of huanglongbing (HLB) in citrus. J Pest Sci 90(1):1-17

Coletta-Filho HD, Targon MLPN, Takita MA, De Negri JD, Pompeu J Jr, Machado MA (2004) First report of the causal agent of huanglongbing (Candidatus Liberibacter asiaticus) in Brazil. Plant Dis $88: 1382$

Coutinho-Abreu IV, Mcinally S, Forster L, Luck R, Ray A (2014) Odor coding in a disease-transmitting herbivorous insect, the Asian Citrus psyllid. Chem Senses 39:539-549. https://doi.org/10.1093/chemse/ bju023

Coyle JF, Lorca GL, Gonzalez CF (2018) Understanding the physiology of Liberibacter asiaticus: an overview of the demonstrated molecular mechanisms. J Mol Microbiol Biotechnol 28:116-127

Doe D, Om N, Dorji C, Dorji T, Garnier M, Jagoueix-Eveillard S, Bové JM (2003) First report of "Candidatus Liberibacter asiaticus", the agent of Citrus Huanglongbing (ex-greening) in Bhutan. Plant Dis $87: 448$

Duran-Vila N, Janse JD, Foissac X, Melgarejo P, Bové JM (2014) Addressing the threat of Huanglongbing in the Mediterranean region: a challenge to save the citrus industry. J Plant Pathol 96 (3) supplement p S4.3-S4.8

Faghih MM, Salehi M, Bagheri A, Izadpanah K (2009) First report of citrus huanglongbing disease on orange in Iran. Plant Pathol 58:793

Garnier M, Jagoueix-Eveillard S, Cronje PR, Le Roux HF, Bove JM (2000) Genomic characterization of a Liberibacter present in an ornamental rutaceous tree, Calodendrum capense, in the Western Cape province of South Africa. Proposal of "Candidatus Liberibacter africanus subsp. capensis.”. Int J Syst Evol Microbiol 50(6):2119-2125

González Hernández AD (2003) Trioza erytreae (Del Guercio 1918): nueva plaga de los c'itricos en Canarias. Phytoma España 153: $112-118$

Gottwald TR (2010) Current epidemiological understanding of citrus huanglongbing. Annu Rev Phytopathol 48:119-139

Gottwald T, Poole G, McCollum T, Hall D, Hartung J, Bai J, Luo W, Posny D, Duan YP, Taylor E, da Graça J, Polek M, Louws F, Schneider W (2020) Canine olfactory detection of a vectored phytobacterial pathogen, Liberibacter asiaticus, and integration with disease control. Proc Natl Acad Sci U S A 117:3492-3501

Gutierrez AP, Ponti L (2013) Eradication of invasive species: why the biology matters. Environ Entomol 42:395-411
Halbert SE, Manjunath KL, Ramadugu C, Brodie MW, Webb SE, Lee RF (2010) Trailers transporting oranges to processing plants move Asian citrus psyllids. Fla Entomol 93:33-38

Hall DG, Hentz MG (2010) Sticky trap and stem-tap sampling protocols for the Asian citrus psyllid (Hemiptera: Psyllidae). J Econ Entomol 103:541-549

Hall DG, Sétamou M, Mizell RF (2010) A comparison of sticky cards for monitoring Asian citrus psyllid (Diaphorina citri Kuwayama). Crop Prot 29:1341-1346

Hall DG, Gottwald TR, Stover E, Beattie GAC (2013) Evaluation of management programs for protecting young citrus plantings from huanglongbing. HortScience 48:330-337

Hansen AK, Trumble JT, Stouthamer R, Paine TD (2008) A new Huanglongbing species, "Candidatus Liberibacter psyllaurous," found to infect tomato and potato, is vectored by the psyllid Bactericera cockerelli (Sulc). Appl Environ Microbiol 74(18): 5862-5865

Holder PW, Stephenson B, Chadfield K, Frampton R (1997) The finding of Mediterranean fruit fly in Auckland, New Zealand and the Ministry of Agriculture's response. The Weta 20(1):4-6

Jagoueix S, Bové JM, Garnier M (1994) The phloem-limited bacterium of greening disease of citrus is a member of the $\alpha$ subdivision of the Proteobacteria. Int J Syst Bacteriol 44:379-386

Jagoueix S, Bové JM, Garnier M (1997) Comparison of the 16S/23S ribosomal Intergenic regions of "Candidatus Liberobacter asiaticum" and "Candidatus Liberobacter africanum", the two species associated with Citrus Huang- longbing (greening) disease. Int J Syst Bacteriol 47:224-227

Janse JD (2012) Bacterial diseases that may or do emerge, with (possible) economic damage for Europe and the Mediterranean basin: notes on epidemiology, risks, prevention and management on first occurrence. J Plant Pathol 94 (4, supplement): S4.5-S4.29

Kalyebi A, Aisu G, Ramathani J, Ogwang J, McOwen N, Russell P (2015) Detection and identification of etiological agents (Liberibacter spp.) associated with citrus greening disease in Uganda. Uganda J Agric Sci 16:43-54

Kean JM, Suckling DM, Sullivan NJ, Tobin PC, Stringer LD, et al. 2015. Global eradication and response database (GERDA). http://b3.net. nz/gerda/index.php

Kruse A, Fleites LA, Heck M (2019) Lessons from one fastidious bacterium to another: what can we learn about. Insects 10

Kumagai LB, LeVesque CS, Blomquist CL, Madishetty K, Guo Y, Woods PW, Rooney-Latham S, Rascoe J, Gallindo T, Schnabel D, Polek M (2013) First report of Candidatus Liberibacter asiaticus associated with Citrus Huanglongbing in California. Plant Dis 97: 283

Lallemand J, Fos A, Bové JM (1986) Transmission de la bactérie associée à la forme africaine de la maladie du «greening» par le psylle asiatique Diaphorina citri Kuwaya- ma. Fruits 41

Leonard MT, Fagen JR, Davis-Richardson AG, Davis MJ, Triplett EW (2012) Complete genome sequence of Liberibacter crescens BT-1. Stand Genom Sci 7(2):271-283

Liefting LW, Perez-Egusquiza ZC, Clover GRG, Anderson JAD (2008) A new "Candidatus Liberibacter" species in Solanum tuberosum in New Zealand. Plant Dis 92(10):1474

Manjunath KL, Ramadugu C, Majil VM, Williams S, Irey M, Lee RF (2010) First report of the Citrus Huanglongbing associated bacterium 'Candidatus Liberibacter asiaticus' from sweet Orange, Mexican lime, and Asian Citrus Psyllid in Belize. Plant Dis 94:781

Mankin RW, Rohde BB, McNeill, SA. 2016. Vibrational duetting mimics to trap and disrupt mating of the devastating Asian citrus psyllid insect pest. Proc. Meet. Acoust . 25: 010006

Martinez Y, Llauger R, Batista L, Luis M, Iglesia A, Collazo C, Pena I, Casin J, Cueto J, Tablada L (2009) First report of 'Candidatus Liberibacter asiaticus' associated with Huanglongbing in Cuba. Plant Pathol 58:389-389 
Massonié G, Garnier M, Bové JM (1976) Transmission of Indian citrus decline by Trioza erytreae (Del Guercio), the vector of South African greening. In: Proceedings of 7 th Conference IOCV, IOCV, Riverside 1976, 18-20

Matos L, Hilf M, Camejo J (2009) First report of 'Candidatus Liberibacter asiaticus' associated with Citrus Huanglongbing in the Dominican Republic. Plant Dis 93:668-668

Merfa MV, Pérez-López E, Naranjo E, Jain M, Gabriel DW, De La Fuente L (2019) Progress and obstacles in culturing 'Candidatus Liberibacter asiaticus', the bacterium associated with Huanglongbing. Phytopathology 109:1092-1101

Monzo C, Arevalo HA, Jones MM, Vanaclocha P, Croxton SD, Qureshi JA, Stansly PA (2015) Sampling methods for detection and monitoring of the Asian citrus psyllid (Hemiptera: Psyllidae). Environ Entomol 44:780-788

Morris J, Shiller J, Mann R, Smith G, Yen A, Rodoni B (2017) Novel 'Candidatus Liberibacter' species identified in the Australian eggplant psyllid, Acizzia solanicola. Microb Biotechnol 10:833-844

Munir S, He P, Wu Y, Khan S, Huang M, Cui W, He Y (2018) Huanglongbing control: perhaps the end of the beginning. Microb Ecol 76:192-204

Myers JH, Hosking G (2002) Eradication. In: Hallman GJ, Schwalbe CP (eds) Invasive arthropods in agriculture - problems and solutions. Science Publishers, Enfield, NH, USA, pp 293-307

Myers JH, Savoie A, van Randen E (1998) Eradication and pest management. Annu Rev Entomol 43:471-491

Nadarasah G, Stavrinides J (2011) Insects as alternative hosts for phytopathogenic bacteria. FEMS Microbiol Rev 35:555-575

Narouei-Khandan HA, Halbert SE, Worner SP, Bruggen AHCV (2016) Global climate suitability of citrus huanglongbing and its vector, the Asian citrus psyllid, using two correlative species distribution modeling approaches, with emphasis on the USA. Eur J Plant Pathol 3:1-16

Pandey SS, Wang N (2019) Targeted early detection of citrus HLB causal agent 'Candidatus Liberibacter asiaticus' before symptom expression. Phytopathology 109:952-959

Phahladira MNB, Viljoen R, Pietersen G (2012) Widespread occurrence of 'Candidatus Liberibacter africanus subspecies capensis' in Calodendrum capense in South Africa. Eur J Plant Pathol 134:39 47

Raddadi N, Gonella E, Camerota C, Pizzinat A, Tedeschi R et al (2011) "Candidatus Liberibacter europaeus" sp. nov. that is associated with and transmitted by the psyllid Cacopsylla pyri apparently behaves as an endophyte rather than a pathogen. Environ Microbiol 13(2):414 426

Roberts R, Pietersen G (2017) A novel subspecies of "Candidatus Liberibacter africanus" found on native Teclea gerrardii (family: Rutaceae) from South Africa. Antonie Van Leeuwenhoek 110: $437-444$

Roberts R, Steenkamp ET, Pietersen G (2015) Three novel lineages of "Candidatus Liberibacter africanus" associated with native rutaceous hosts of Trioza erytreae in South Africa. Int J Syst Evol Microbiol 65(Pt. 2):723-731

Roberts R, Cook G, Grout TG, Khamis F, Rwomushana I, Nderitu PW, Seguni Z, Materu CL, Steyn C, Pietersen G, Ekesi S, le Roux HF (2017) Resolution of the identity of 'Candidatus Liberibacter' species from Huanglongbing-affected Citrus in East Africa. Plant Dis 101:1481-1488

Saponari M, De Bac G, Breithaupt J, Loconsole G, Yokomi RK, Catalano L (2010) First report of 'Candidatus Liberibacter asiaticus' associated with Huanglongbing in sweet Orange in Ethiopia. Plant Dis 94: 482
Sétamou M, Flores D, French JV, Hall DG (2008) Dispersion patterns and sampling plans for Diaphorina citri (Hemiptera: Psyllidae) in citrus. J Econ Entomol 101:1478-1487

Sétamou M, Sanchez A, Saldaña RR, Patt JM, Summy R (2014) Visual responses of adult Asian citrus psyllid (Hemiptera: Liviidae) to colored sticky traps on citrus trees. J Insect Behav 27:540-553

Shigesada N, Kawasaki K (1997) Biological invasions: theory and practice. Oxford University Press, Oxford, p 205

Shimwela MM, Narouei-Khandan HA, Halbert SE, Keremane M, Minsavage GV, Timilsina S, Massawe DP, Jones JB, AHC, v.B (2016) First occurrence of Diaphorina citri in East Africa, characterization of the $\mathrm{Ca}$. Liberibacter species causing Huanglongbing (HLB) in Tanzania, and potential further spread of D. citri and HLB in Africa and Europe. Eur J Plant Pathol 146:346-368

Siverio F, Noales EM, Bertolinix E, Teresani GR, Peñalver J et al (2017) Survey of huanglongbing associated with 'Candidatus Liberibacter' species in Spain: analyses of citrus plants and Trioza erytreae. Phytopathol Mediterr 56:98-110

Stansly PA, Qureshi JA, Arevalo A (2009) Why, when and how to monitor and manage the Asian citrus psyllid. Citrus Ind 90:23-24

Suckling DM, Barrington AM, Chhagan A, Stephens AEA, Burnip GM, Charles JG, Wee SL (2007). Eradication of the Australian painted apple moth Teia anartoides in New Zealand: trapping, inherited sterility, and male competitiveness. In M. J. B. Vreysen, A. S. Robinson, \& J. Hendricks (Eds.), Area- wide control of insect pests (pp. 603-615). Vienna, ustria: International Atomic Energy Agency

Texeira DC, Ayres AJ, Kitajima EW, Tanaka FAO, Danet JL, JagoueixEveillard S, Saillard C, Bové JM (2005) First report of a Huanglongbing-like disease of Citrus in Sao Paulo state, Brazil, and Association of a new liberib- acter species, "Candidatus Liberibacter americanus", with the disease. Plant Dis 89

Thomas DB (2012) Comparison of insect vacuums for sampling Asian citrus psyllid (Homoptera: Psyllidae) on citrus trees. Southwest Entomol 37:55-60

Thompson S, Fletcher JD, Ziebell H, Beard S, Panda P et al (2013) First report of "Candidatus Liberibacter europaeus" associated with psyllid infested scotch broom. New Dis Rep 27:6

Tobin PC, Kean JM, Suckling DM, McCullough DG, Herms DA, Stringer LD (2014) Determinants of successful arthropod eradication programs. Biol Invasions 16:401-414

Verma DPS (1992 Apr) Signals in root nodule organogenesis and endocytosis of rhizobium. Plant Cell 4(4):373-382

Wang N (2019) The Citrus Huanglongbing crisis and potential solutions. Mol Plant 12:607-609

Wang N, Trivedi P (2013) Citrus huanglongbing: a newly relevant disease presents unprecedented challenges. Phytopathology 103:652-665

Wang N, Pierson EA, Setubal JC, Xu J, Levy JG, Zhang Y, Li J, Rangel LT, J., M. (2017) The Candidatus Liberibacter-host interface: insights into pathogenesis mechanisms and disease control. Annu Rev Phytopathol

Zanardi OZ, Volpe HXL, Favaris AP, Silva WD, Luvizotto RAG, Magnani RF, Esperança V, Delfino JY, de Freitas R, Miranda MP et al (2018) Putative pheromone of the Asian citrus psyllid, Diaphorina citri, breaks down into an attractant. Sci Rep 8:455

Zheng Z, Chen J, Deng X (2018) Historical perspectives, management, and current research of Citrus HLB in Guangdong Province of China, where the disease has been endemic for over a hundred years. Phytopathology 108:1224-1236

Publisher's note Springer Nature remains neutral with regard to jurisdictional claims in published maps and institutional affiliations. 